\title{
Effect of Different Irregularities on Low Rise to High Rise Structures
}

\author{
Kaveri S. Kulkarni ${ }^{1}$, Ms. P.K. Pardakhe ${ }^{2}$ \\ ${ }^{1}$ ME Student \\ Jagadamba College of Engineering \& Technology, Yavatmal, India, 445001 \\ ${ }^{2}$ Assistant Professor \\ Jagadamba College of Engineering \& Technology, Yavatmal, India, 445001
}

Received on: 04 May,2021, Revised on: 30 May,2021, $\quad$ Published on: 31 May, 2021

\begin{abstract}
The behavior of a building during an earthquake depends on several factors such as stiffness, lateral strength, and ductility, simple and regular configurations. The buildings with regular geometry, uniformly distributed mass and stiffness in plan as well as in elevation suffer much less damage compared to irregular configurations. But nowadays thirst and demand of the new generation engineers are planning towards an irregular configuration for better aesthetic perspective. Hence earthquake engineering has developed the key issues in understanding the role of different types of building configurations. Seismic analysis is a division of structural analysis and it involves the calculation of the different response of a building structure subjected to earthquakes with different irregularities.
\end{abstract}

Keywords- Response spectrum method, ETAB, IS 1893:2016, Plan irregularity, stiffness irregularity

\section{I- INTRODUCTION}

$\mathbf{I}_{\mathrm{r}}$ regular buildings constitute a large portion of the modern urban infrastructure. Structures are never perfectly regular and hence the designers routinely need to evaluate the likely degree of irregularity and the effect of this irregularity on a structure during an earthquake. Need for research is required to get economical \& efficient lateral stiffness system for high seismic prone areas. For optimization \& design of high rise building with different structural framing systems subjected to seismic loads. To improve the understanding of the seismic behavior of building structures with different irregularities.

Objectives:

1. To check the analysis results of ETABS for lateral stability checks as per IS code 1893:2016 provisions for seismic loads.

2. Analysis of 5 storied, 10 storied and 15 storied RC framed structure with different irregularities under seismic conditions. Irregularities considered are Reentrant corner, mass irregularity, vertical geometric irregularity, plan irregularity and stiffness irregularity.

3. To calculate the response of buildings subjected to seismic zone IV using response spectrum and to compare the results.

4. Study the effect of seismic responses such as the storey lateral displacement, storey drift, storey shear, storey stiffness and mode period in zone IV.

\section{II- PROBLEM STATEMENT}

Six storey $(\mathrm{G}+5)$, Eleven storey $(\mathrm{G}+10)$ and Sixteen storey $(\mathrm{G}+15)$ reinforced concrete frame buildings have been considered \& analyzed with the help of ETAB software by using Response spectrum method. Following properties are considered for buildings.

Analysis Property Data

a) Material used was M40 Grade Concrete.

b) Yield stress fy $=500 \mathrm{~N} / \mathrm{mm} 2$ 


\section{International Journal of Innovations in Engineering and Science, www.ijies.net}

c) Compressive Cube Strength of Concrete $=25 \mathrm{~N} / \mathrm{mm} 2$

d) Poisson's ratio $=0.15$

e) Analysis was done using ETABS Software 9.7

Building Details

a) Type of frame: Special RC moment resisting frame fixed at the base

b) Number of storey: $\mathrm{G}+5, \mathrm{G}+10, \mathrm{G}+15$

c) Ground Floor height: $3 \mathrm{~m}$

d) Floor height: $3.0 \mathrm{~m}$

e) Depth of Slab: $120 \mathrm{~mm}$

f) Size of beam: $(250 \times 800) \mathrm{mm}$

g) Size of column: $(400 \times 900) \mathrm{mm}$

h) Spacing between frames : (i) $6 \mathrm{~m}$ in $\mathrm{X} \& \mathrm{Y}$ direction (General),

(ii) $30 \mathrm{~m} \times 24 \mathrm{~m}$ in $\mathrm{X} \& \mathrm{Y}$

direction

i) Live load on floor: $2 \mathrm{kN} / \mathrm{m} 2$

j) Floor finish: $1.0 \mathrm{kN} / \mathrm{m} 2$

m) Thickness of wall: $230 \mathrm{~mm}$

o) Density of concrete: $25 \mathrm{kN} / \mathrm{m} 3$

p) Density of masonry wall: $19 \mathrm{kN} / \mathrm{m} 3$

Depth of foundation from ground level $=1.5 \mathrm{~m}$

Seismic Data

a) Type of soil: Medium

b) Seismic zone: IV

c) Importance factor: 1.2

d) Reduction factor: 5

e) Response spectra: As per IS 1893(Part-1):2016

s) Damping of structure: 5 percent

\section{III- MODELING}

The main aim of the model is to study the change in building responses (mainly deflection and storey drift) due to various irregularities as pee IS 1893:2016. The building is analyzed in 6 stages as follows,
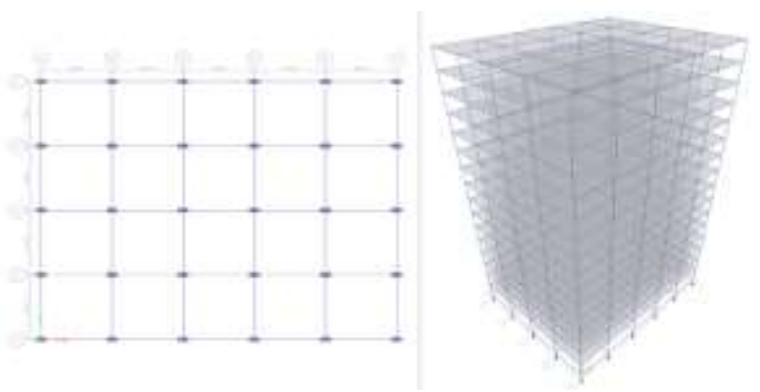

Fig. 1-Plan \& isometric view of regular structure

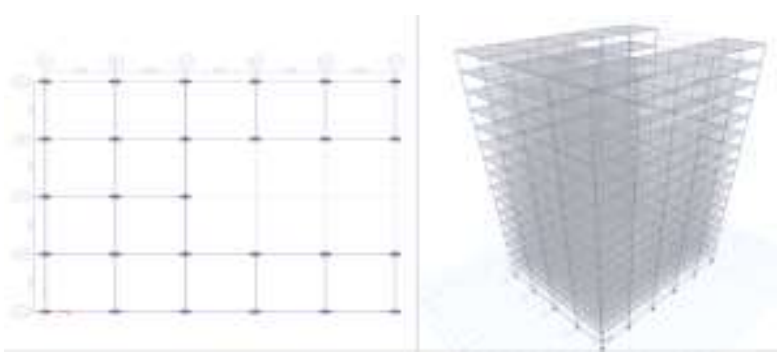

Fig. 2- Plan \& isometric view of Structure with plan irregularity

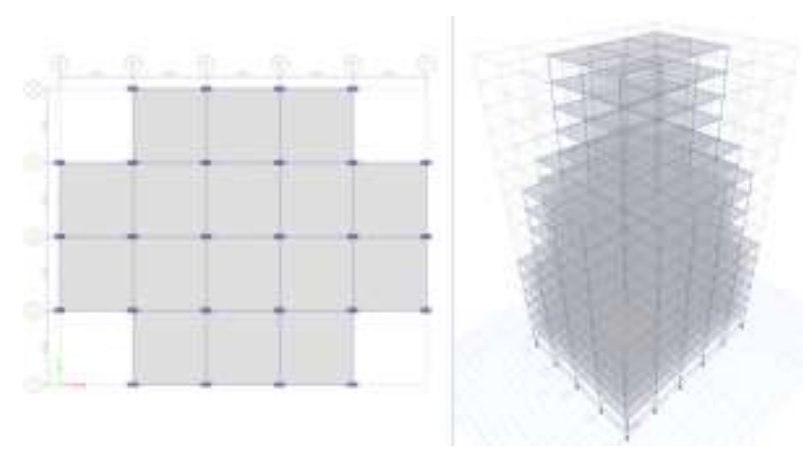

Fig. 3-Plan \& isometric view of Structure with vertical irregularity

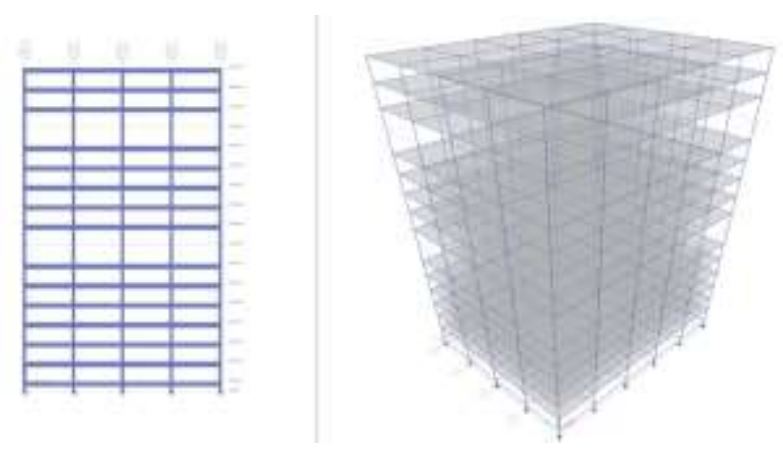

Fig. 4- Elevation \& isometric view of Structure with stiffness irregularity

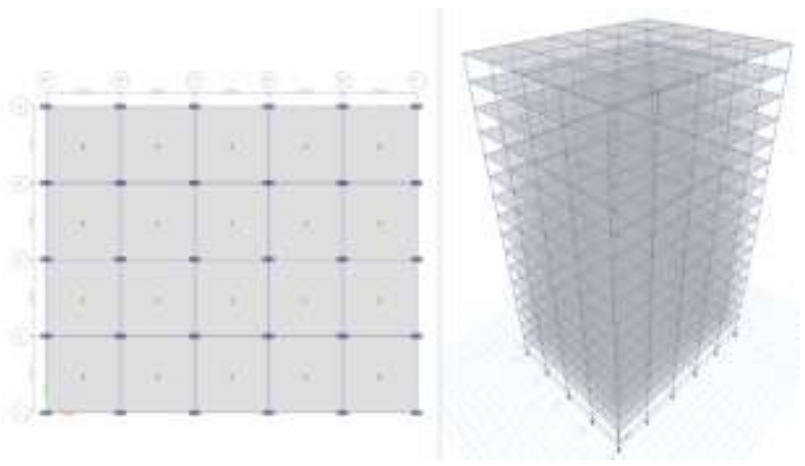

Fig. 5- Plan \& isometric view of Structure with mass irregularity 
International Journal of Innovations in Engineering and Science, www.ijies.net
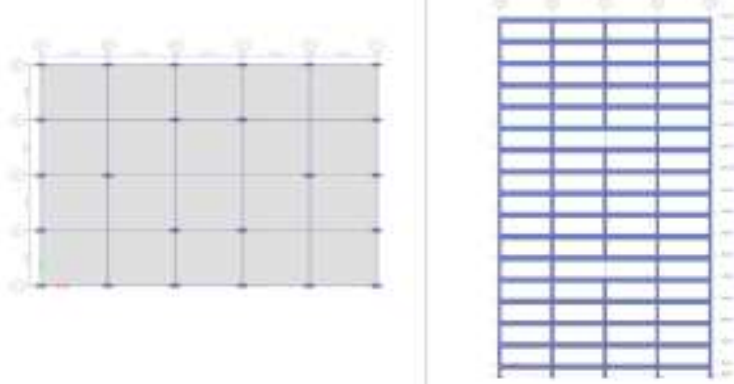

Fig. 6- Plan \& Elevation of Structure with strength irregularity

\section{IV- RESULTS}

Table 1-Base shear $(k N)$ in $X$-direction

\begin{tabular}{|c|c|c|c|c|c|c|}
\hline $\begin{array}{c}\text { Type } \\
\text { of } \\
\begin{array}{c}\text { Struc } \\
\text { ture }\end{array}\end{array}$ & $\begin{array}{c}\text { Regul } \\
\text { ar } \\
\text { struct } \\
\text { ure }\end{array}$ & $\begin{array}{c}\text { Struct } \\
\text { ure } \\
\text { with } \\
\text { plan } \\
\text { irregul } \\
\text { arity }\end{array}$ & $\begin{array}{c}\text { Struct } \\
\text { ure } \\
\text { with } \\
\text { vertic } \\
\text { al } \\
\text { irregul } \\
\text { arity }\end{array}$ & $\begin{array}{c}\text { Struct } \\
\text { ure } \\
\text { with } \\
\text { stiffne } \\
\text { ss } \\
\text { irregul } \\
\text { arity }\end{array}$ & $\begin{array}{c}\text { Struct } \\
\text { ure } \\
\text { with } \\
\text { mass } \\
\text { irregul } \\
\text { arity }\end{array}$ & $\begin{array}{c}\text { Struct } \\
\text { ure } \\
\text { with } \\
\text { streng } \\
\text { th } \\
\text { irregul } \\
\text { arity }\end{array}$ \\
\hline G+5 & 3721. & 2903. & 3783. & 3100. & 3760. & 3709. \\
& 1648 & 39 & 62 & 48 & 02 & 9 \\
\hline G+1 & 7108. & 5556. & 6575. & 6491. & 7149. & 7090. \\
0 & 5254 & 11 & 72 & 15 & 61 & 51 \\
\hline G+1 & 7239. & 5660. & 5425. & 6386 & 7292. & 7228. \\
5 & 7738 & 18 & 95 & 96 & 81 \\
\hline
\end{tabular}

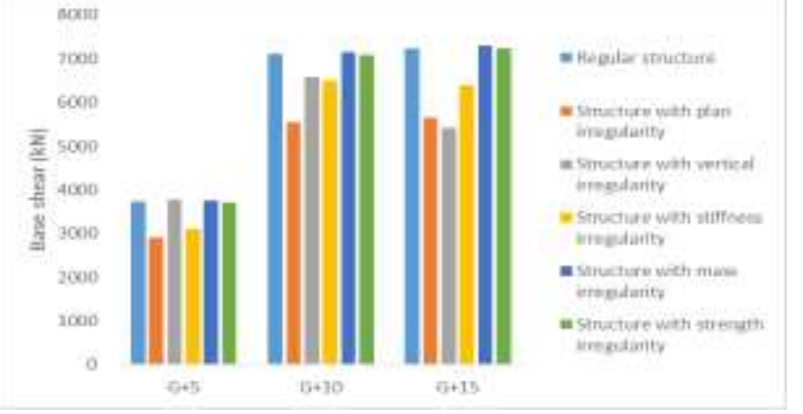

Fig. 7- Base shear $(k N)$ in $X$-direction

Table 2-Base shear $(k N)$ in $Y$-direction

\begin{tabular}{|c|c|c|c|c|c|c|}
\hline $\begin{array}{c}\text { Type } \\
\text { of } \\
\text { Struc } \\
\text { ture }\end{array}$ & $\begin{array}{l}\text { Regu } \\
\text { lar } \\
\text { struc } \\
\text { ture }\end{array}$ & $\begin{array}{l}\text { Struct } \\
\text { ure } \\
\text { with } \\
\text { plan } \\
\text { irregul } \\
\text { arity }\end{array}$ & $\begin{array}{c}\text { Struct } \\
\text { ure } \\
\text { with } \\
\text { vertica } \\
1 \\
\text { irregul } \\
\text { arity }\end{array}$ & $\begin{array}{l}\text { Struct } \\
\text { ure } \\
\text { with } \\
\text { stiffne } \\
\text { ss } \\
\text { irregul } \\
\text { arity }\end{array}$ & $\begin{array}{c}\text { Struct } \\
\text { ure } \\
\text { with } \\
\text { mass } \\
\text { irregul } \\
\text { arity }\end{array}$ & $\begin{array}{l}\text { Struct } \\
\text { ure } \\
\text { with } \\
\text { strengt } \\
\mathrm{h} \\
\text { irregul } \\
\text { arity }\end{array}$ \\
\hline $\mathrm{G}+5$ & $\begin{array}{c}3719 \\
.99\end{array}$ & 2604.9 & $\begin{array}{c}3781.5 \\
3\end{array}$ & $\begin{array}{c}3099.9 \\
6\end{array}$ & $\begin{array}{c}3760.8 \\
7\end{array}$ & $\begin{array}{c}3710.0 \\
9\end{array}$ \\
\hline $\begin{array}{c}\mathrm{G}+1 \\
0\end{array}$ & $\begin{array}{c}6381 \\
.6\end{array}$ & $\begin{array}{c}4987.9 \\
1\end{array}$ & $\begin{array}{c}5903.9 \\
8\end{array}$ & $\begin{array}{c}5826.8 \\
1\end{array}$ & $\begin{array}{c}6418.4 \\
5\end{array}$ & $\begin{array}{c}6379.7 \\
5\end{array}$ \\
\hline $\begin{array}{c}\mathrm{G}+1 \\
5\end{array}$ & $\begin{array}{c}6474 \\
.81\end{array}$ & $\begin{array}{c}5064.0 \\
9\end{array}$ & $\begin{array}{c}4854.4 \\
3\end{array}$ & $\begin{array}{c}5710.2 \\
4\end{array}$ & $\begin{array}{c}6523.9 \\
8\end{array}$ & $\begin{array}{c}6464.9 \\
3\end{array}$ \\
\hline
\end{tabular}

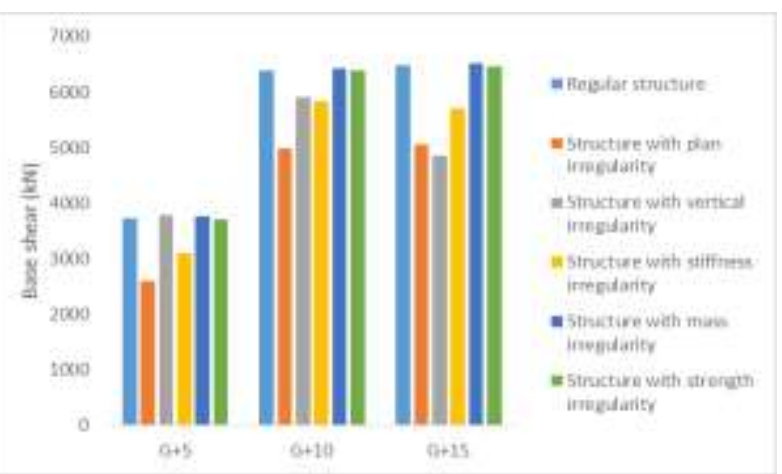

Fig. 8- Base shear $(k N)$ in Y-direction

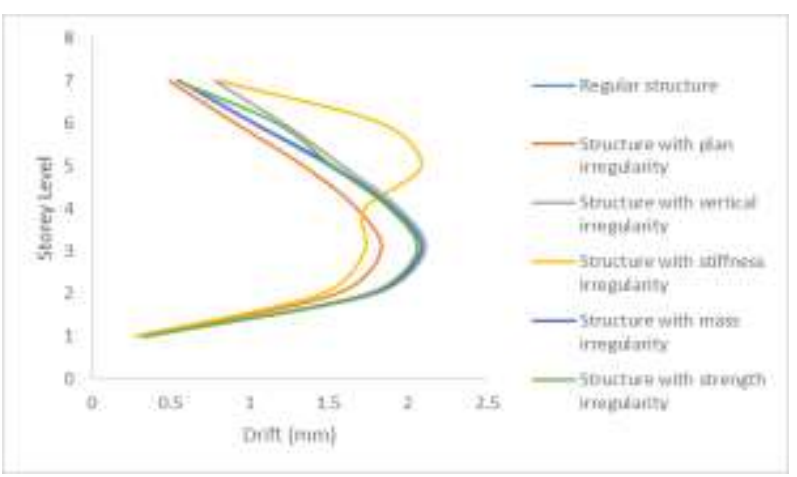

Fig. 9- Storey Drift ( $\mathrm{mm})$ in X-direction $(G+5)$ building

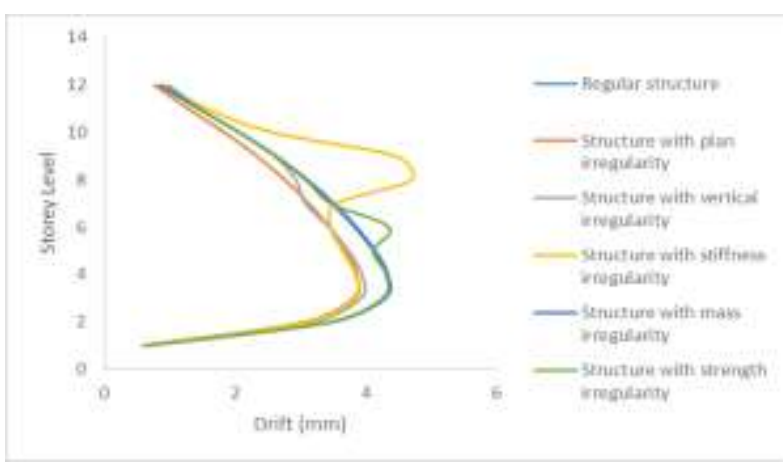

Fig. 10- Storey Drift ( $\mathrm{mm})$ in X-direction $(G+10)$ building

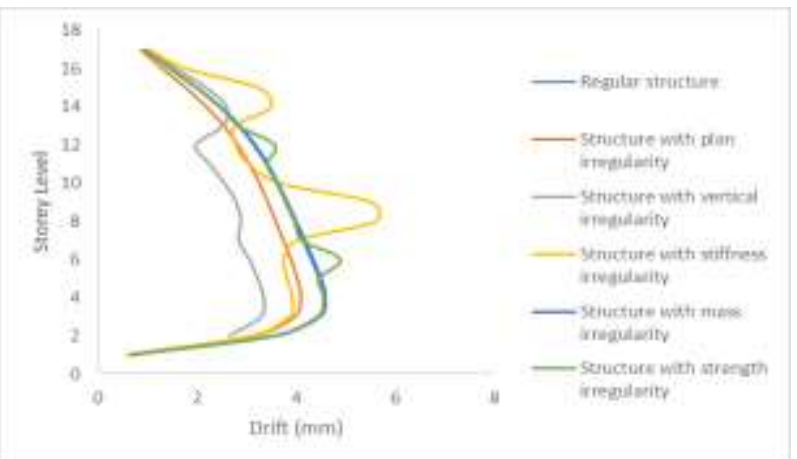

Fig. 11- Storey Drift (mm) in X-direction $(G+15)$ building 
International Journal of Innovations in Engineering and Science, www.ijies.net

Table 3- Maximum axial force $(k N)$ in columns

\begin{tabular}{|c|c|c|c|c|c|c|}
\hline $\begin{array}{l}\text { Type } \\
\text { of } \\
\text { Struc } \\
\text { ture }\end{array}$ & $\begin{array}{l}\text { Regu } \\
\text { lar } \\
\text { struct } \\
\text { ure }\end{array}$ & $\begin{array}{l}\text { Struct } \\
\text { ure } \\
\text { with } \\
\text { plan } \\
\text { irregul } \\
\text { arity }\end{array}$ & $\begin{array}{c}\text { Struct } \\
\text { ure } \\
\text { with } \\
\text { vertica } \\
1 \\
\text { irregul } \\
\text { arity }\end{array}$ & $\begin{array}{c}\text { Struct } \\
\text { ure } \\
\text { with } \\
\text { stiffne } \\
\text { ss } \\
\text { irregul } \\
\text { arity }\end{array}$ & $\begin{array}{c}\text { Struct } \\
\text { ure } \\
\text { with } \\
\text { mass } \\
\text { irregul } \\
\text { arity }\end{array}$ & $\begin{array}{c}\text { Struct } \\
\text { ure } \\
\text { with } \\
\text { strengt } \\
\mathrm{h} \\
\text { irregul } \\
\text { arity }\end{array}$ \\
\hline $\mathrm{G}+5$ & 67 & 19 & $\begin{array}{r}4063.9 \\
97\end{array}$ & $\begin{array}{r}3188.3 \\
78\end{array}$ & 7 & $\begin{array}{r}4349.7 \\
43\end{array}$ \\
\hline $\begin{array}{c}\mathrm{G}+1 \\
0\end{array}$ & $\begin{array}{c}7249 . \\
73\end{array}$ & $\begin{array}{c}6766.2 \\
9\end{array}$ & $\begin{array}{c}7222.2 \\
1\end{array}$ & $\begin{array}{c}6619.2 \\
4\end{array}$ & $\begin{array}{c}7411.1 \\
8\end{array}$ & $\begin{array}{c}9019.3 \\
1\end{array}$ \\
\hline $\begin{array}{c}\mathrm{G}+1 \\
5\end{array}$ & $\begin{array}{c}104 \\
8\end{array}$ & $\begin{array}{c}567.0 \\
2\end{array}$ & 9813.1 & וגולות & $\begin{array}{c}10788 . \\
6\end{array}$ & $\begin{array}{c}12929 . \\
6\end{array}$ \\
\hline
\end{tabular}

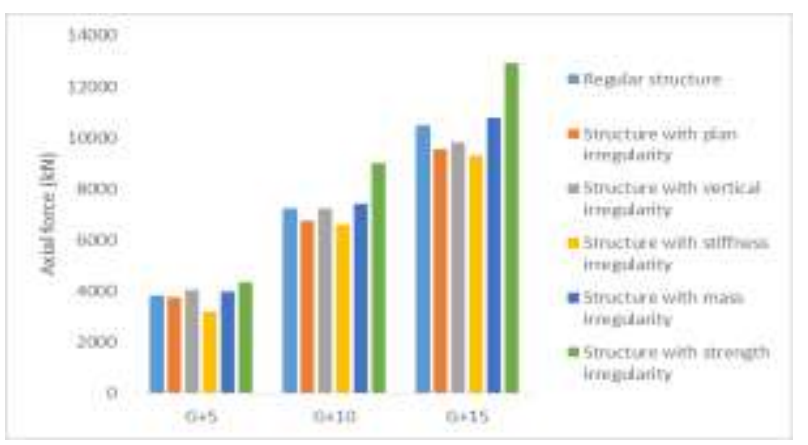

Fig. 12- Maximum axial force $(k N)$ in columns

Table 4- Maximum moment ( $k N m)$ in beams

\begin{tabular}{|c|c|c|c|c|c|c|}
\hline $\begin{array}{c}\text { Type } \\
\text { of } \\
\begin{array}{c}\text { Struc } \\
\text { ture }\end{array}\end{array}$ & $\begin{array}{c}\text { Regu } \\
\text { lar } \\
\text { struc } \\
\text { ture }\end{array}$ & $\begin{array}{c}\text { Struct } \\
\text { ure } \\
\text { with } \\
\text { plan } \\
\text { irregul } \\
\text { arity }\end{array}$ & $\begin{array}{c}\text { Struct } \\
\text { ure } \\
\text { with } \\
\text { vertica } \\
1\end{array}$ & $\begin{array}{c}\text { Struct } \\
\text { ure } \\
\text { irregul } \\
\text { arity } \\
\text { stiffne } \\
\text { ss } \\
\text { irregul } \\
\text { arity }\end{array}$ & $\begin{array}{c}\text { Struct } \\
\text { ure } \\
\text { with } \\
\text { mass } \\
\text { irregul } \\
\text { arity }\end{array}$ & $\begin{array}{c}\text { Struct } \\
\text { ure } \\
\text { with } \\
\text { strengt } \\
\text { h } \\
\text { irregul } \\
\text { arity }\end{array}$ \\
\hline $\mathrm{G}+5$ & 438. & 408.51 & 445.90 & 378.07 & 441.87 & 443.71 \\
& 194 & 4 & 6 & 7 & 7 & 7 \\
\hline $\mathrm{G}+1$ & 695. & 697.46 & 653.88 & 641.86 & 699.21 & 715.41 \\
0 & 937 & 3 & 9 & 9 & 5 & 1 \\
\hline $\mathrm{G}+1$ & 707. & 728.37 & 568.99 & 633.72 & 712.19 & 743.40 \\
5 & 716 & 3 & 6 & 8 & 2 & 2 \\
\hline
\end{tabular}

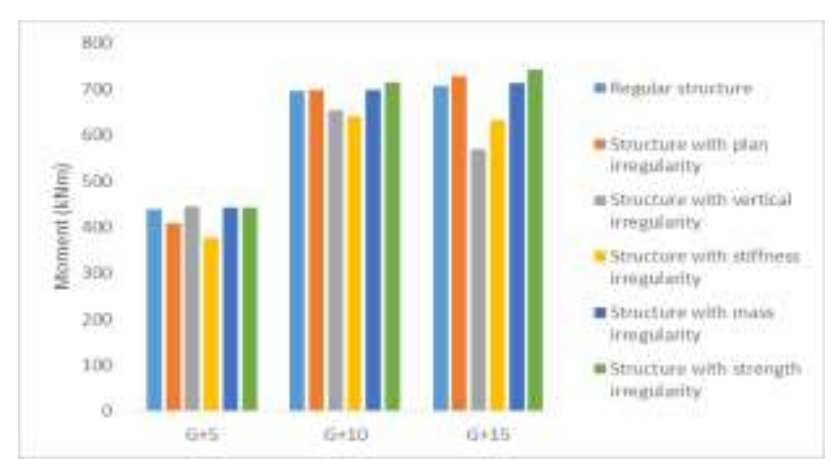

Fig. 13- Maximum moment $(\mathrm{kNm})$ in beams

\section{V- CONCLUSION}

1. In $X$ direction, Lateral force or storey shear at each consecutive storey level for mass irregularity is more as compared to other types of irregularity. Vertical irregularity has least lateral force on consecutive story's as compared to other types of irregularity. Approximately on an average 15\% lateral force or storey shear is decreased or increased between all studied types of irregularities.

2. In Y direction, Lateral force or storey shear at each consecutive storey level for regular structure is more as compared to other types of irregularity. Vertical irregularity has least lateral force on consecutive story's as compared to other types of irregularity. Approximately on an average 15\% lateral force or storey shear is decreased or increased between all studied types of irregularities.

3. Storey drift ratio for stiffness irregularity is more as compared to other types of irregularity. mass irregularity has least drift ratio as compared to other types of irregularity. Approximately on an average $25 \%$ storey drift is decreased or increased between all studied types of irregularities.

4. Axial force in column is rise upto $30 \%$ in building with strength irregularity as compared to regular structure.

5. Moment in beam is rise upto $35 \%$ in building with strength irregularity as compared to regular structure.

\section{ACKNOWLEDGMENT}

I am thankful to Ms. P.K. Pardakhe, Asst. Professor Civil Engineering, Jagadambha College Of Engineering And Technology, Yavatmal, India. My guide and my beloved friends for their timely help rendered and the immense support extended for the submission of this paper.

\section{REFERENCES}

[1] Poonam, Anil Kumar And Ashok K. Gupta (2012). Study Of Response Of Structurally Irregular Building Frames To Seismic Excitations, International Journal of Civil, Structural, Environmental and Infrastructure Engineering Research and Development (IJCSEIERD) ISSN 22496866 Vol.2, Issue 2 25-31

[2] Anibal G Costa, Carlos S Oliveira and Ricardo T Duarte (1988). Influence of Vertical Irregularities on Seismic Response of Building, proceedings to ninth world conference on Earthquake Engineering, August 2-9, 1988 Tokyo Japan. 
Vol. 6, No. 5, 2021, PP. 10- 14

International Journal of Innovations in Engineering and Science, www.ijies.net

[3] G.F. Dargush , M.L. Green and Y. Wang(2004). Evolutionary Aseismic Design and Retrofit of Passively Damped Irregular Structures, 13th World Conference on Earthquake Engineering Vancouver, B.C., Canada August 1-6, 2004 Paper No. 1899.

[4] Devesh P. Soni and Bharat B. Mistry (2006). Qualitative Review Of Seismic Response Of Vertically Irregular Building Frames, ISET Journal of Earthquake Technology, Technical Note, Vol. 43, No. 4, December 2006, pp. 121-132.

[5] IS: 1893(Part1):2016. Criteria for Earthquake resistant design of structures, Bureau of Indian Standards.

[6] Yasser Alashker, SohaibNazar (2015). Effects of Building Configuration on Seismic Performance of RC Buildings by PushoverAnalysis, Open Journal of Civil Engineering, 2015.

[7] Snehal s. Pawarl, sanjaybhadke, Priyanka kamble (2016). Seismic Analysis of VerticallyIrregular RC Building, International Journal of Current Trends in Engineering \& Research (IJCTER)e-ISSN 2455-1392, Volume 2 Issue 4, April 2016. 